\title{
Evaluation of Visual Function Requirements for Public Jobs in Saudi Arabia
}

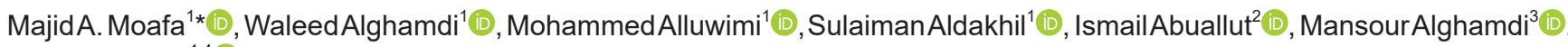 \\ Saif Alrasheed ${ }^{1,4}$ (D) \\ ${ }^{1}$ Department of Optometry, College of Applied Medical Sciences, Qassim University, Buraydah, Saudi Arabia; ${ }^{2}$ Faculty of Medicine, \\ Jazan University, Jizan, Saudi Arabia; ${ }^{3}$ Department of Optometry, College of Applied Medical Sciences, King Saud University, Riyadh, \\ Saudi Arabia; ${ }^{4}$ Department of Binocular Vision, Faculty of Optometry and Visual Sciences, Al-Neelain University, Khartoum, Sudan
}

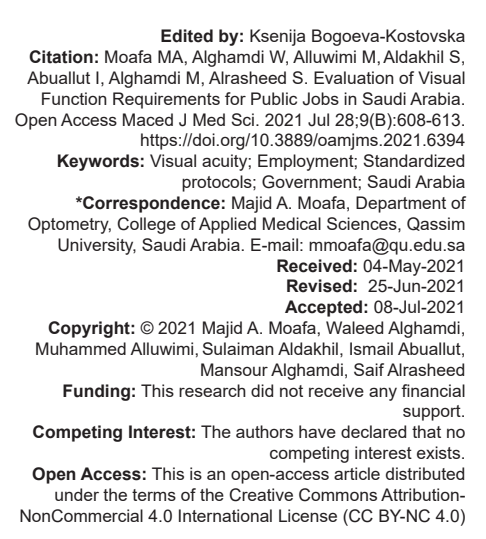

\section{Abstract}

BACKGROUND: Certain occupations and career paths require potential candidates who meet certain visual standards that allow them to apply or hold realistic possibilities for career advancement.

AIM: This study aims to assess the visual function requirements for public jobs in Saudi Arabia and compare them with international standards.

METHODS: Interview with eye care specialists in the fields of optometry and ophthalmology was conducted. This interview was consisted of seven pre-approved questions on current vision health requirements for eyesightdependent careers.

RESULTS: Interview responses revealed the existence of several visual requirements which were visual acuity, color vision, and visual field. These requirements are essential for various government jobs and functions, with examinations of applicants being necessary for acceptance of a vacancy or subsequent career progression.

CONCLUSION: Many government positions of employment require predefined level visual standards which are not widely known. Defining what these standards are and making them publicly accessible will aid both future candidates in better planning their employment options and specialists in providing the required standards on request.

\section{Introduction}

There are specific levels of visual functions standard that is necessary for performing various jobrelated activities [1]. These standards of occupationrelated visual ability are important for both employee and employer, resulting in more worker tailored job placement, leading to greater safety and job satisfaction for the employee, and increased productivity for the employer [2]. It is unfortunate that a standardized reference of minimum visual functions requirements in relation to job position or career path does not exist in any reliable location or accessible form [1], [2], [3], [4]. The absence or lack of standardized reference of minimum visual requirements may lead to insufficient visual ability. Consequently, there would be significant increased probability of serious or deadly accidents, such as in the aviation industry [5], [6].

Establishing a minimum level of visual competency in function of desired occupation, measured by a series of quantifiable parameters, would greatly aid in addressing this current deficit [1], [2], [3]. Possible parameters that have been proposed include visual acuity, color perception, contrast sensitivity, binocular, and peripheral visual field sensitivity, as these are important visual functions associated with many on-thejob proficiencies, as well as based on documented cases of severe accident or death [4].

One such case was the mandatory introduction of color discrimination testing for marine watch keepers, train drivers, and other monitoring position at the $19^{\text {th }}$ century. This was established because of two fatal accidents attributed to inherited red-green (RG) deficiency [7], [8], [9]. In 1919, the International Civil Air Navigation Authority (ICAN) established color vision standards for the aviation industry, and nearly in 1930 , color vision standards were used for road transportation in the United Kingdom [10], [11], [12]. At present, it is standard policy in the United Kingdom for the Health and Safety Administrative Board to notify candidates that certain careers require normal color vision, for either reasons of safety or quality of product such as armed forces, railways, navigation, merchant shipping, hospital technicians, and pharmacists [9].

At present, each country builds its own standards of acceptable visual requirements based on 
national rules and the specific employer's assessment of minimum risk-free requirements. Consequently, each occupation has priority visual functions that differ from each other, such as aviation emphasizes visual field sensitivity and color vision, while the police force requires normal near and distance visual acuity as selection parameters for recruitment. In Saudi Arabia, there is no standardized reference for visual requirements for the occupational purposes. In this study, we aimed to assess the occupational vision standards for different professions in Saudi Arabia and compare them with international standards.

\section{Methods}

The study was a qualitative, cross-sectional, interview-based study, conducted in five main Saudi hospitals (i.e., the army forces, National Guard, security forces, civil service, and aviation institute hospitals) between May and August 2020. The interview consisted of seven questions regarding visual functions assessment and minimum vision standard requirements for each main career choice. The questions were as follows:

1. What are the visual functions needed for each occupation?

2. Who does conduct the visual functions tests?

3. Where are the visual functions tests performed?

4. How are the visual functions tests done? Unaided or aided? Monocular or binocular

5. What are the minimum requirements for each visual function test to accept the applicants?

6. If the applicants have eye disorders such as ptosis or manifest squint but their vision is good, what will you do?

7. When will employee be considered as a retired?

The interviews were completed in face to face with 20 participants who were heads of department or resident field experts in optometry and ophthalmology, and perform vision tests for eyesight-dependent careers. These interviews were taken place in the optometry and ophthalmology clinics where these clinicians work. The interviews were recorded as the participants answers the questions. Clarifications for the seven questions were provided to the participants as needed.

\section{Results}

The responses for the participants indicated that the most common visual functions required for the eyesightdependent careers were visual acuity, color vision. and visual field. Answers were summarized as follows:

\section{Visual acuity (VA)}

The prospective candidates for the National Guard are divided into two groups:

- Group A consists of field operations and their VA must be $6 / 6$ without correction.

- Group B consists of all other positions and clerical staff. These were permitted 6/9 VA with present correction.

For the armed forces and aviation applicants, the response was similar, dividing applicants in two categories, that of soldier in which their VA must be 6/9 in one eye and $6 / 6$ in the other or better; the second being officer rank and their VA must be $6 / 9$ in one eye and $6 / 18$ or better in the other. LASIK surgery is acceptable for both groups.

The security forces applicants also have similar procedures to the armed forces group division, but the requirement values were different in which the soldier's vision must be 6/12 each eye or better, glasses and contact lens were not acceptable, where the officer's vision is 6/9 each eye or one eye $6 / 6$ and the other $6 / 12$. LASIK surgery is acceptable for both categories.

Conversely, ministry officials required the same VA as that for obtaining a driving license. For public driving (heavy vehicle), the vision must be $6 / 6$ in both eyes and in private driving the vision must be $6 / 9$ in one eye and the other 6/6, as shown in Table 1.

\section{Color vision}

The applicants for National Guard underwent color vision deficiency examination by Ishihara 21 Plates test. The candidates were allowed a total of five mistakes, with immediate dismissal at the $6^{\text {th }}$.

Table 1: Visual functions requirements for different careers in Saudi Arabia

\begin{tabular}{|c|c|c|c|}
\hline Occupation & Visual acuity & Color vision & Visual field \\
\hline Armed forces & $\begin{array}{l}\text { Level one: Soldiers } \\
\text { At least one eye } 6 / 9 \text { and the } \\
\text { other } 6 / 6 \text { Lasik surgery should } \\
\text { be considered carefully } \\
\text { Level two: Officers } \\
\text { At least one eye } 6 / 9 \text { and } \\
\text { other } 6 / 18\end{array}$ & $\begin{array}{l}\text { Level one: Soldiers } \\
\text { Ishihara } 21 \text { Plates }> \\
4 \text { mistakes } \rightarrow \text { fail } \\
<4 \rightarrow \text { acceptable } \\
\text { Level two: Officers } \\
>5 \text { mistakes } \rightarrow \text { fail } \\
<5 \rightarrow \text { acceptable }\end{array}$ & Normal \\
\hline National Guard & At least best-corrected $V A \geq 6 / 9$ & $\begin{array}{l}\text { Ishihara } 21 \text { Plates } \\
>5 \text { mistakes } \rightarrow \text { fail }\end{array}$ & Normal \\
\hline Security forces & $\begin{array}{l}\text { Level one: soldiers } \\
\text { At least VA } \geq 6 / 12 \text { each eye } \\
\text { Glasses and contact lens not } \\
\text { accepted while Lasik surgery } \\
\text { accepted } \\
\text { Level two: officers } \\
\text { At least } 6 / 9 \text { in either eye or } \\
\text { one eye } 6 / 6 \text { and other } 6 / 12\end{array}$ & $\begin{array}{l}\text { Level one: Soldiers } \\
\text { Ishihara } 21 \text { Plates }> \\
5 \text { mistakes } \rightarrow \text { fail } \\
<5 \rightarrow \text { acceptable } \\
\text { Level two: Officers } \\
>5 \text { mistakes } \rightarrow \text { fail } \\
<5 \rightarrow \text { acceptable }\end{array}$ & Normal \\
\hline Civil service & $\begin{array}{l}\text { Public driving (heavy vehicle) } \\
\text { Best-corrected VA } \geq 6 / 6 \\
\text { Private driving } 6 / 9 \text { in one eye } \\
\text { and the other } 6 / 6 \text { is acceptable }\end{array}$ & ( & - \\
\hline Aviation & $\begin{array}{l}\text { Level one: Soldiers } \\
\text { At least one eye } 6 / 9 \text { and the } \\
\text { other } 6 / 6 \text { Lasik surgery should } \\
\text { be considered carefully } \\
\text { Level two: Officers } \\
\text { At least one eye } 6 / 9 \text { and } \\
\text { other } 6 / 18\end{array}$ & $\begin{array}{l}\text { Level One: Soldiers } \\
\text { Ishihara } 21 \text { Plates }> \\
4 \text { mistakes } \rightarrow \text { fail } \\
<4 \text { is acceptable } \\
\text { Level two: Officers } \\
>5 \text { mistakes } \rightarrow \text { fail } \\
<5 \rightarrow \text { acceptable }\end{array}$ & Normal \\
\hline
\end{tabular}


The candidates for armed forces, security forces, and aviation were divided into two groups. The soldier applicants were considered as passed if they did not exceed four mistakes total on Ishihara color vision test. However, security forces applicants for the second group could make five mistakes before dismissal (Table 1).

\section{Visual field}

Each agency is extremely strict about the examination of visual field; applicants must pass the test. Normal visual filed is described as the following: Measuring $90^{\circ}$ temporally to central fixation, $50^{\circ}$ superiorly and nasally, and $60^{\circ}$ inferiorly. In addition, each candidate must undergo fundus examination to ensure that the posterior eye segment is normal (Table 1).

In the National Guard hospital, they did a cover test for candidate to assess the ocular balance because they do not accept applicants with binocular anomalies.

In the civil services, they performed refraction if uncorrected refractive errors were suspected. Applicants with reduced vision (less than 6/6) were referred to the optometrist or the ophthalmologist clinic or a primary health care center.

\section{Clinical procedures and minimum requirements of visual functions}

Tests were conducted by eye care professionals (an optometrist or an ophthalmologist), except for civil services in which the investigation was performed in the medical fitness clinic by physician. Nevertheless, if the applicants had any visual problems, they would be referred to optometry clinic for further investigation. On the other hand, there were two phases of assessment in the armed force hospital and aviation institute. First, examination was performed in the training center for general inspections such as VA, weight, and height. This was followed by other examinations in visual field, color vision, and refraction. These examinations were monocularly conducted, nonetheless, in the Ministry of Civil Services was monocularly and binocularly performed. The eye care professions reported that the test done twice for applicants with glasses and without glasses (should correction be allowed).

Applicants with ocular conditions such as manifest squint and ptosis were rejected to entering the professions of armed force, security force, and aviation without appeal. However, the above mention candidates with eye disorders were accepted in the National Guard and Ministry of Civil if these disorders do not affect the candidates VA. According to the regulations in the profession's employee, cases with reduced vision of $6 / 60$ or worse were referred to the medical committee to make the decision on their retirement, as shown in Table 2.

\section{Discussion}

Vision standards for occupations have always significant differences between organizations. This made it difficult for eye care professionals to advise patients interested in their profession. Certain occupations and career paths require potential candidates who meet certain visual standards that allow them to apply or hold realistic possibilities for career advancement. It is, therefore, important to the individual and the hiring entities that proper screening and appropriate selection standards be developed for assessing of individuals to correctly direct finite resources. Thus, we conducted this study to assess the occupational vision standards for different governmental professions in Saudi Arabia and compare them with the international standards. Global visual standards revealed a wide range of requirements, with variations between country to another and region to another in one country. Good visual acuity $6 / 6$ is commonly called for, with the

Table 2: Clinical procedures and minimum requirements for occupation-related visual functions in Saudi Arabia

\begin{tabular}{|c|c|c|c|c|c|}
\hline & Armed forces & National Guard & Security forces & Civil service & Aviation \\
\hline $\begin{array}{l}\text { Who conducts } \\
\text { tests? }\end{array}$ & $\begin{array}{l}\text { Optometrist/ } \\
\text { ophthalmologist }\end{array}$ & $\begin{array}{l}\text { Optometrist/ } \\
\text { ophthalmologist }\end{array}$ & Optometrist/ophthalmologist & $\begin{array}{l}\text { Optometrist/ } \\
\text { ophthalmologist }\end{array}$ & $\begin{array}{l}\text { Optometrist/ } \\
\text { ophthalmologist }\end{array}$ \\
\hline Where & $\begin{array}{l}\text { Training center (VA) } \\
\text { After the acceptance: } \\
\text { VA, Visual field, color } \\
\text { vision, and refraction in } \\
\text { hospital }\end{array}$ & $\begin{array}{l}\text { Training center at the } \\
\text { National Guard }\end{array}$ & $\begin{array}{l}\text { Three centers in Riyadh: } \\
\text { Medical committee } \\
\text { King Fahad security college } \\
\text { Training center }\end{array}$ & In different hospitals & $\begin{array}{l}\text { Training center (VA) } \\
\text { After the acceptance: } \\
\text { VA, Visual field, color } \\
\text { vision, and refraction in } \\
\text { hospital }\end{array}$ \\
\hline $\begin{array}{l}\text { Unaided or aided } \\
\text { monocular or } \\
\text { binocular }\end{array}$ & $\begin{array}{l}\text { Unaided } \\
\text { monocular }\end{array}$ & $\begin{array}{l}\text { Both aided and } \\
\text { unaided } \\
\text { All the tests were } \\
\text { monocular }\end{array}$ & $\begin{array}{l}\text { Both aided and unaided } \\
\text { All the tests were } \\
\text { monocular }\end{array}$ & $\begin{array}{l}\text { Both aided and } \\
\text { unaided } \\
\text { Both monocular and } \\
\text { binocular }\end{array}$ & $\begin{array}{l}\text { Unaided } \\
\text { Monocular }\end{array}$ \\
\hline $\begin{array}{l}\text { Minimum } \\
\text { requirement }\end{array}$ & $\begin{array}{l}\text { Treatable eye } \\
\text { conditions were } \\
\text { acceptable }\end{array}$ & $\begin{array}{l}\text { Treatable eye } \\
\text { conditions were } \\
\text { acceptable } \\
\text { Color blindness was } \\
\text { rejected }\end{array}$ & $\begin{array}{l}\text { Each test considered as a } \\
\text { unit if candidate failed in } \\
\text { one unit (test) was rejected } \\
\text { Except treatable eye } \\
\text { conditions were acceptable }\end{array}$ & $\begin{array}{l}\text { Treatable eye } \\
\text { conditions were } \\
\text { acceptable }\end{array}$ & $\begin{array}{l}\text { Treatable eye conditions } \\
\text { were acceptable }\end{array}$ \\
\hline $\begin{array}{l}\text { Ptosis or tropia with } \\
\text { VA } 6 / 6\end{array}$ & Acceptable & Acceptable & Rejected & Acceptable & Rejected \\
\hline $\begin{array}{l}\text { When the employee } \\
\text { will be considered } \\
\text { as a retired }\end{array}$ & $\begin{array}{l}\mathrm{VA} \leq 6 / 60 \\
\text { Employee will refer to } \\
\text { medical committee to } \\
\text { make decision }\end{array}$ & $\begin{array}{l}\mathrm{VA} \leq 6 / 60 \\
\text { Employee will refer to } \\
\text { medical committee to } \\
\text { make decision }\end{array}$ & $\begin{array}{l}\text { Employee will be retired in } \\
\text { any case }\end{array}$ & $\begin{array}{l}V A \leq 6 / 60 \\
\text { Employee will refer } \\
\text { to medical committee } \\
\text { to make decision }\end{array}$ & $\begin{array}{l}\mathrm{VA} \leq 6 / 60 \\
\text { Employee will refer to } \\
\text { medical committee to } \\
\text { make decision }\end{array}$ \\
\hline
\end{tabular}


requirement for unaided vision varying between $6 / 12$ and $6 / 60$. Majority standards for color perception asked for normal or near normal such as mild anomalous trichromacy [13], [14], [15].

This study found that the system followed in examination and eyesight standards is almost same in the studied governmental professions in Saudi Arabia except the Ministry of Civil Services, which only required the testing of visual acuity. Comparable to London police recruits focus on testing distance and near vision and color vision [13]. However, the color vision function examined by City University test in the UK and in Saudi Arabia by Ishihara the disadvantage of this test only detects congenital redgreen defect, furthermore, near vision not included in Saudi standards, as shown in tables 1 and 3. The visual function standards for army in the present study were in accordance with the USA army requirements, the vision of every soldier was evaluated at distance and near. Those capable of uncorrected $6 / 6$ vision in each eye at each distance underwent no further vision evaluation [16], [17]. The normal visual acuity in the general populations is $6 / 6$, with $89 \%$ of people achieving $6 / 6$ or better in at least one eye and a further only $8 \%$ achieving 6/7.5 [18], [19]. The required vision standards for security forces officers in Saudi Arabia were at least $6 / 9$ in either eye or one eye 6/6 and other $6 / 12$. This was acceptable since it is conceivable that an individual would see $6 / 12$ in the poor eye and still achieve $6 / 6$ binocularly. These professional standards accept monocular individuals and those with significant poor vision in one eye (amblyopia) as long as their good eye achieves $6 / 6$ or better so that they meet the binocular visual acuity standards. Conversely, the applicants with monocular vision had a slightly reduced field of view as compared to binocular view and would of course have no stereopsis, but this was not believed to be dangerous for the career based on the visual task analysis.

Table 3: National eyesight standards for forces in the UK [13]

\begin{tabular}{ll}
\hline Eyesight & Standards requirements \\
\hline Unaided vision & - At least $6 / 12$ or better in either eye. \\
& - And $6 / 6$ or better binocularly, and N6 binocularly at $40 \mathrm{~cm}$. \\
Visual acuity & - At least $6 / 12$ or better in either eye and $6 / 6$ or better binocularly \\
Color vision & - At least 7 out of 10 correct responses on the City University test \\
& - Severe color vision deficiencies (monochromats) are not \\
& acceptable. \\
& - Anomalous trichromats and dichromats are acceptable. \\
- The use of color correcting lenses is not acceptable & - Rejected if candidate with a history of retinal detachment or \\
Eye conditions & glaucoma. \\
& - Squint lens implants and corneal grafts with good unaided \\
vision can be considered, along with congenital eye conditions & \\
Refractive surgery & Radial keratotomy rejected. \\
& - Interviewees who have undertaken photorefractive keratoplasty \\
& surgery' should be considered carefully.
\end{tabular}

Color vision is particularly important to a person's understanding of their visual world and daily activities, and those with color vision defect might experience difficulties in everyday life. Nonetheless, adaptive plans and behaviors could help to deal with any potential problems they face in both their profession and daily activities. Some degree of color deficiency occurs in $8.0 \%$ and $0.5 \%$ among males and females, respectively, with congenital red-green deficiencies predominating [20], [12]. Consequently, a substantial proportion of potential workers specifically men may be excluded by color vision standards. Many forces in Saudi Arabia require the applicants to pass 16 out of 21 plates on the Ishihara test. This slightly is different from the methods used in the UK where the applicants need to pass 7 out of 10 plates on the second edition City University test, excluding all but the mildest of anomalous trichromats. Chisholm [13] revealed that the defective color vision is not a safety issue and hence rational adjustment needs to be made to accommodate color deficiency in individuals, and to avoid the discrimination against them. In Saudi Arabia, the testing of color vision is strict for the force and aviation. The applicants were considered pass the examination if the made only four mistakes on Ishihara color vision test, this like United States army aircrew protection [17], [22], [23].

Good peripheral visual filed was identified as an important attribute for army force and police officers to aid evidence gathering and the rapid detection of features of interest. The current study revealed that, in Saudi Arabia, each organization is very stringent about the examination of visual field the applicants should have to pass this test. This in line with the QinetiQ report suggested that confrontation combined with an automated of central visual fields examination be used to confirm a binocular visual field of at least $120^{\circ}$ horizontally by $100^{\circ}$ vertically, with no significant defects within the central $50^{\circ}$ [24], [25]. The minimum visual field requirement for driving in the UK is at least $120^{\circ}$ horizontally, moreover, there cannot be significant defects in the binocular field within $20^{\circ}$ of fixation above or below the horizontal meridian [26]. However, in the US, California does not have visual field requirements for driving. The standards of visual filed for New York and lowa are comparable to the standards in Saudi Arabia. In New York, for persons with corrected visual acuity of $<20 / 40$ but not $<20 / 70$, the horizontal binocular field of vision must not be < $140^{\circ}$ [27].

According to the regulations in the army force in Saudi Arabia, officers with reduced vision of $6 / 60$ or worse were referred to the medical committee to make the decision on their retirement. This agrees with Chisholm [13] reported that it would have been highly informative to interview serving officers whose eyesight has deteriorated with age or been damaged by injury such that they no longer meet the recruitment standards. The current study had some limitations: The sample size was small, the study covered only two regions which were Riyadh and Qassim. Thus, it is recommended that future studies increase the sample size to include most of the governmental professions in different regions of Saudi Arabia. 


\section{Conclusion}

Agencies have vision standards and procedures for the acceptance of the applicants to a wide range of professions. Some of these professions have resemblances in visual functions tests, procedures, and acceptance requirements. Therefore, it is critical to provide a systematic method of defining the vision requirements for various essential job functions. The eye care providers can refer to these vision standards when advising interested patients or completing eyesight forms for applicants to any professionals in Saudi Arabia. Standards for visual function tests in Saudi Arabia are similar to the international standards regarding the visual acuity assessment, but slightly different in the color vision test. For the visual field assessment, the standards in Saudi Arabia are similar to those in the UK and the USA, but the UK requires visual field assessment for drivers while Saudi Arabia and the USA do not.

\section{Authors' Contributions}

All authors made substantial contributions to conception and design, acquisition of data, or analysis and interpretation of data; took part in drafting the article or revising it critically for important intellectual content; agreed to submit to the current journal; gave final approval of the version to be published; and agree to be accountable for all aspects of the work.

\section{References}

1. Johnson CA. Occupational psychophysics to establish vision requirements. Optom Vis Sci. 2008;85(10):910-23.

PMid: 18832974

2. Good GW, Weaver JL, Augsburger AR. Determination and application of vision standards in industry. $A m \mathrm{~J}$ Ind Med. 1996;30(5):633-40. https://doi.org/10.1002/ (sici)1097-0274(199611)30:5<633:aid-ajim12>3.0.co;2-4 PMid:8909613

3. Holroyd E, Hall DM. A re-appraisal of screening for colour vision impairments. Child Care Health Dev. 1997;23(5):391-8. https:// doi.org/10.1111/j.1365-2214.1997.tb00906.x PMid:9339766

4. Johnson CA. Vision requirements for driver's license examiners. Optom Vis sci. 2005;82(8):779-89.

PMid:16127345

5. Vygolov OV. Enhanced and synthetic vision systems development based on integrated modular avionics for civil aviation. In: 2013 IEEE/AIAA 32 ${ }^{\text {nd }}$ Digital Avionics Systems Conference (DASC); 2013. p. 2B5-1. https://doi.org/10.1109/ dasc.2013.6719614
6. Ginsburg AP. Contrast sensitivity, drivers' visibility, and vision standards. Transp Res Rec. 1987;1149:32-39.

7. Birch J, Rodríguez-Carmona M. Occupational color vision standards: New prospects. J Opt Soc Am A Opt Image Sci Vis. 2014;31(4):A55-9. https://doi.org/10.1364/josaa.31.000a55 PMid:24695202

8. Vingrys AJ, Cole BL. Origins of colour vision standards within the transport industry. Ophthalmic Physiol Opt. 1986;6(4):36975. https://doi.org/10.1111/j.1475-1313.1986.tb01155.x

9. Cumberland P, Rahi JS, Peckham CS. Impact of congenital colour vision defects on occupation. Arch Dis Child. 2005;90(9):906-8. PMid: 15914497

10. Koefoed VF, Miles T, Cason JB, Troche R. Colour vision classification-comparing CAD and CIE 143: 2001 International recommendations for colour vision requirements in transport. Acta Ophthalmol. 2020;98(7):726-35. https://doi.org/10.1111/ aos. 14450

PMid:32385912

11. Bailey KG, Carter T. Consistency of secondary colour vision tests in transport industries. Occup Med (Lond). 2016;66(4):26875. https://doi.org/10.1093/occmed/kqw012 PMid:27162253

12. Vingrys AJ, Cole BL. Are colour vision standards justified for the transport industry? Ophthalmic Physiol Opt. 1988;8(3):257-74. https://doi.org/10.1111/j.1475-1313.1988.tb01056.x PMid:3269506

13. Chisholm CM. New vision standards for police constable recruits. Optom Pract. 2005;6(3):131-40.

14. Currie Z, Bhan A, Pepper I. Reliability of Snellen charts for testing visual acuity for driving: Prospective study and postal questionnaire. BMJ. 2000;321(7267):990-2. https://doi. org/10.1136/bmj.321.7267.990 PMid:11039964

15. Shapley R, Nunez V, Gordon J. Cortical double-opponent cells, and human colour perception. Curr Opin Behav Sci. 2019;30:1-7.

16. Mason KT, Shannon SG, Slattery MJ. US Army Aviation Epidemiology Data Register: Incidence of Colour Vision Deficiency among US Army aviators, ADA296977. Fort Rucker, AL: Army Aeromedical Research Laboratory; 1995. p. 1-21. https://doi.org/10.21236/ada373106

17. Weaver JL, McAlister WH. Vision readiness of the reserve forces of the US army. Mil Med. 2001;166(1):64-6. https://doi. org/10.1093/milmed/166.1.64 PMid:11197101

18. Sorsby A, Sheridan M, Leary GA, Benjamin B. Vision, visual acuity, and ocular refraction of young men. Br Med $\mathrm{J}$. 1960;1(5183):1394-8. https://doi.org/10.1136/bmj.1.5183.1394 PMid:13832932

19. Alrasheed SH, Naidoo KS, Clarke-Farr PC. Prevalence of visual impairment and refractive error in school-aged children in South Darfur State of Sudan. Afr Vis Eye Health. 2016;75(1):1-9. https://doi.org/10.4102/aveh.v75i1.355

20. Birch J. Worldwide prevalence of redgreen colour deficiency. J Opt Soc Am A Opt Image Sci Vis. 2012;29:31320. PMid:22472762

21. Alrasheed SH, Awad ME, Abdulbagi AA, Abdu M. Congenital and acquired colour vision deficiency among population in North Kordofan State of Sudan. Sudanese J Ophthalmol. 2017;9(1):22-7. https://doi.org/10.4103/sjopthal.sjopthal_5_17

22. Rodriguez-Carmona M, O'Neill-Biba M, Barbur JL. Assessing the severity of color vision loss with implications for aviation and other occupational environments. Aviat Space Environ Med. 2012;83(1):19-29. https://doi.org/10.3357/asem.3111.2012 
PMid:22272512

23. Rash CE, Wilson ML, Adams MS, Harding TH, McLean WE, Walsh DV, et al. Colour and Its Integration into US Army RotaryWing Cockpits: A White Paper No. AD1077787. Fort Rucker, AL: Army Aeromedical Research Laboratory; 2019. p. 1-33.

24. Lisboa R, Chun YS, Zangwill LM, Weinreb RN, Rosen PN, Liebmann JM, et al. Association between rates of binocular visual field loss and vision-related quality of life in patients with glaucoma. JAMA Ophthalmol. 2013;131(4):486-94. https://doi. org/10.1001/jamaophthalmol.2013.2602

PMid:23450425

25. Coeckelbergh TR, Brouwer WH, Cornelissen FW, van Wolffelaar P, Kooijman AC. The effect of visual field defects on driving performance: A driving simulator study. Arch
Ophthalmol. 2002;120(11):1509-16. https://doi.org/10.1001/ archopht.120.11.1509

\section{PMid:12427065}

26. Chisholm CM, Rauscher FG, Crabb DC, Davies LN, Dunne MC Edgar DF, et al. Assessing visual fields for driving in patients with paracentral scotomata. Br J Ophthalmol. 2008;92(2):22530. https://doi.osrg/10.1136/bjo.2007.129726

PMid:17962396

27. Bron AM, Viswanathan AC, Thelen $U$, de Natale R, Ferreras A, Gundgaard J, et al. International vision requirements for driver licensing and disability pensions: Using a milestone approach in characterization of progressive eye disease. Clin Ophthalmol. 2010;4:1361-9. https://doi.org/10.2147/opth.s15359

PMid:21179219 